\title{
FORMATION OF I.I. MECHNYKOV'S SCIENTIFIC CREATIVITY IN HIS YOUTH
}

УДК 159.954-043.86:[929:001]

DOI https://doi.org/10.32843/2663-

5208.2020.12-2.2

\section{Виноградова В.Є.}

к.пед.н., доцент, завідувач кафедри психології та педагогіки

Таврійський національний університет імені В.І. Вернадського у статті розглядається процес фрормування наукової творчості видатного вченого I.I. Мечникова. Метою статmі є дослідити основні чинники, які вплинули на розвиток наукового і творчого мислення I.I. Мечникова в процесі навчання в університеті. Приділена увага мікросередовищу Іллі Ілліча. Аналізуються освітні умови, які можуть стати дієвими щодо фоормування творчого мислення особистості. Досліджуються роки навчання Іллі Ілліча в Харківському університеті на природничому фракультеті. Розглядаються питання фоормування наукової творчості особистості залежно від умов освітнього середовища. Аналізується вплив профресорського складу на формування профресійних інтересів I.I. Мечникова. Узагальнено найбільш значущі фрактори, які впливають на розвиток наукової творчості, а також бар'єри розвитку творчості. Приділяється увага його дослідженням і науковому колу інтересів. Аналізуються захоплення Іллі Ілліча, які безпосередньо вплинули на фоорування світогляду майбутнього науковця. Простежується подальше навчання за кордоном та етапи профресійного становлення I.I. Мечникова. Досліджуються фрактори, що впливають на формування наукового таланту в умовах звичайного життя I.I. Мечникова.

Визначено, що вагомий вплив на фрормування наукового мислення особистості чинить близьке університетське оточення й інші системи макросередовища. Аналіз студентських років Іллі Ілліча Мечникова характеризує особливості розвитку його наукового мислення та фоормування таланту. До основних фракторів, що вплинули на розвиток наукового мислення I.I. Мечникова, зараховано такі чинники: вища освіта в провідному університеті країни; високий рівень загальних здібностей; активна позиція в освітньому прочесі, тісна взаємодія з професорсько-викладацьким складом (на нього впливала плеяда видатних учених того часу, зокрема профресори О.М. Бекетов та І.П. Щелков); активнаучасть удослідженнях університету; високий рівень мотивації та постійний саморозвиток майбутнього науковця; можливість самостійно обирати власну траєкторію й темп навчання. Ключові слова: І.І. Мечников, наукова діяльність, наукова творчість, особистість, талант, творчість.
The article deals with the process of formation of scientific creativity of the outstanding scientist I.I. Mechnykov. The main goal of the article is to study the main factors that influenced the development of I.I. Mechnykov's scientific and creative thinking in the process of study ing at university. Attention has been paid to the microenvironment of Illya llich. The educational conditions that can become effective in the formation of a personality's creative thinking have been analysed. The years of study of Illya llich at Kharkiv University at the Faculty of Natural Sciences have been researched. The questions of the formation of a personality's scientific creativity depending on the conditions of educational environment have been considered. The influence of the academic staff on the formation of I.I. Mechnykov's professional interests has been analysed. The most important factors that influence the development of scientific creativity, as well as the barriers to creative development, have been summarized. Attention has been paid to his research activities and scientific interests. Illya llich's hobbies which directly influenced the formation of the future scientist's outlook have been analysed. His further study abroad and the stages of his professional formation have been traced. The factors influencing the formation of scientific talent in Mechnykov's ordinary life of have been researched.

It has been determined that a close university environment and other macroenvironment systems affect the formation of the personality's scientific thinking. The analysis of Illya Ilich Mechnykov's student years characterizes the features of his scientific thinking development and the formation of his talent. The main factors that influenced the development of Mechnykov's scientific thinking included higher education at a country's leading university, high level of general abilities, active position in the educational process, close interaction with the teaching staff (it was influenced by a galaxy of outstanding scientists of that time, in particular, professors A. Beketov and I. Shchelkov), active participation in university research, high level of motivation and constant self-development of the future scientist, the ability to choose his own trajectory and pace of learning independently. Key words: I.I. Mechnykov, scientific activity, scientific creativity, personality, talent, creativity.
Постановка проблеми. Сьогодні питанню розвитку наукової творчості в студентів приділяється особлива увага. На жаль, наука в Україні немає достатнього фінансування й не $€$ доволі популярною в молоді. Однак прогрес іде вперед, і незначний відсоток студентів усетаки захоплюється науковими дослідженнями та робить відкриття. Періодично, узнаючи з новин про нові доробки та винаходи молодих людей, отримуємо задоволення й відчуття гордості за націю та талановиту молодь. Також варто відмітити, що сьогодні вища освіта перебуває в пошуку нової сучасної ідентифікації. Тому варто звернутися до історичних освітніх традицій, які допоможуть з'ясувати та оновити психолого-педагогічні чинники, що сприяють розвитку особистості.

Отже, на нашу думку, необхідно дослідити умови, які спонукають і стають розвивальним середовищем для майбутніх науковців. Тому актуальним, на наш погляд, $є$ розгляд впливу університетського оточення та психологічних 
факторів розвитку наукової творчості особистості. Звернемось до постаті нобелівського лауреата І.І. Мечникова. Його відкриття є вагомими у світовій науці, сьогодні, у час пандемії, ї неможливо переоцінити.

Видатний науковець зробив неоціненний внесок у розвиток зоології, мікробіології, ембріології, імунології. Ілля Ілліч є автором п'яти фундаментальних відкриттів, серед них - теоретичне і практичне обґрунтування внутрішньоклітинного травлення; розкриття сутності запалення; створення фагоцитарної теорії імунітету; учення про антибіотики; розвиток концепції довголіття. І.І. Мечников був талановитим педагогом і створив потужну наукову школу, у якій навчалися майбутні біологи й лікарі світового рівня [11].

Аналіз останніх досліджень і публікацій. Сучасні науковці досліджують спадщину I.I. Мечникова під кутом різних наукових галузей. Щодо педагогічної діяльності, то цей напрям вивчає низка науковців. Дисертаційна робота Н.В. Зайцевої присвячена аналізу педагогічних поглядів І.І. Мечникова. Вона відзначає, що I.I. Мечникова можна назвати педагогом-новатором, який розробив нові підходи до навчально-виховного процесу. На думку дослідниці, новизна його педагогічних підходів до навчання виявлялася в побудові лекцій, у їх підготовці, мотиваційному змісті, простоті викладу з обов'язковим збереженням наукової точності й достовірності. Побудова навчання на матеріалі, який формує мотивацію до навчання, стимулює інтерес до досліджуваної проблеми, усе це підштовхувало студентів до самоосвіти й професійного розвитку. І.Б. Чень, Г.Б. Гуменюк досліджують наукову діяльність Іллі Ілліча. Також аспекти життєдіяльності І.І. Мечникова вивчали такі науковці, як А.Є. Гайсинович, В.А. Догель, С.Я. Залкінд, В.П. Могилевский, В.В. Хижняков та інші. Останніми роками наукові праці йому присвячували такі автори, як П.Т. Петрюк, І.Ю. Кучма, В.І. Резник досліджували біографічні, наукові та психіатричні аспекти життєдіяльності І.І. Мечникова; Р.А. Галушка, І.Ю. Кучма, Л.І. Глазунова розглядали наукову діяльність І.І. Мечникова за кордоном.

Постановка завдання. Метою статті $€$ дослідити основні фактори формування наукової творчості І.І. Мечникова. Завдання дослідження полягає: 1) в аналізі наукової літератури із цієї проблематики; 2) у розкритті основних чинників, що впливають на розвиток наукової творчості студента.

Виклад основного матеріалу дослідження. Відповідно до вікової періодизації, юнацький вік триває в межах 15-23 років. Тому нами буде розглянуто саме цей період життя I.I. Мечникова.

Під час навчання в гімназії Ілля старанно працював, дотримувався розпорядку дня.
Він почав вивчення природи з околиць рідної Панасівки ще у восьмирічному віці, а в п'ятнадцять став вивчати найпростіших. Спостерігаючи за одноклітинними організмами, Ілля Ілліч дійшов розуміння, що в природі все досить просто й логічно, ця простота й лягла в основу його методів дослідження.

Щоб мати можливість серйозніше працювати, І.І. Мечников вирішив познайомитися з професорами Харківського університету. Неймовірно, однак учнем шостого класу Харківської гімназії він став відвідувати лекції університету. Спочатку він прийшов на лекцію з порівняльної анатомії та звернувся до професора Масловського з проханням дозволити зайнятися протоплазмами найпростіших під його керівництвом. Професор прийняв його доволі стримано й повчальним тоном сказав, що він рано захотів узятися за наукові питання. Професор порадив І.І. Мечникову спочатку закінчити гімназію, а вже потім вступати до університету й займатися науковою діяльністю [6]. Однак це не вплинуло на бажання I.I. Мечникова займатися наукою, він продовжував відвідувати лекції викладачів університету. Поступово він накопичував знання значно глибші, ніж ті, що він отримував у гімназії. Через деякий час він звернувся до молодого професора І.П. Щелкова, який викладав фізіологію. Цього разу йому пощастило: І.П. Щелков погодився давати І.І. Мечникову приватні уроки. Його лекції дуже подобалися молодому вченому. І.І. Мечников мріяв знайти в лабораторіях заохочення й можливість, нарешті, узятися за справжню наукову роботу. Під керівництвом І.П. Щелкова Ілля Мечников познайомився з основами гістології.

Захоплений теорією Вірхова, І.І. Мечников прагнув зробити вагомий внесок у наукову медицину, він мріяв створити якесь нове медичне вчення. Ілля Ілліч намагався всіляко розширити свої знання: він з ентузіазмом цікавився наукою та багато читав. Разом з однокласником В.В. Зеленським вони перекладали з французької мови роботу науковця Грове «Єдність фізичних сил». Грове доводив взаємне перетворення різних видів енергії один в одного. Це не було новиною в науці. М.В. Ломоносов ще раніше зробив відкриття про єдиний закон збереження матерії й енергії. Закон став наріжним каменем природничих наук. Увага гімназиста I.І. Мечникова до цієї найбільшої проблеми природознавства слугує свідченням раннього формування його наукових інтересів.

Зацікавившись роботою юнаків, учитель гімназії Тихонович, який викладав природознавство та хімію, став допомагати їм у ній. Отже, перекладам був присвячений весь навчальний рік. Згодом відомий зоолог, академік В.В. Зеленський писав: «Ми знаходили 
час для читання серйозних книг, наукових творів; із відомих наукових питань писали реферати, влаштовували диспути ...» [5].

Варто відмітити, що, крім науки, І.І. Мечников також захоплювався музикою й театром. І.А. Сеченов пригадував про І.І. Мечникова: «... він був великий любитель музики, умів наспівувати безліч класичних речей, любив театр» $[10$, c. 136$]$.

I.I. Мечников намагався користуватися кожною вільною хвилиною для своїх занять. Навіть під час «нецікавих» уроків він читав наукові книги. Потім він описував у спогадах цікавий випадок про те, що під час уроку закону божого, зачитавшись, він не помітив, як до нього підійшов батюшка, який узяв у нього книгу з рук. Виявилося, що І.І. Мечников читав твір Радлькофера «Про тіла, що містять кристали протеїну». Прочитавши наукову назву роботи, батюшка мовчки повернув йому книгу й більше ніколи не турбував його.

На час канікул І.П. Щелков позичив Іллі мікроскоп, він міг у Панасівці добре вивчати місцеву фауну найпростіших. Юнаку відкрилися цікаві картини життя невидимих істот. Коли I.І. Мечников вивчав інфузорій, йому здалося, що він помітив деякі ще невідомі науці явища. Усі спостереження він ретельно занотовував у зошит дослідів. Пізніше на їх підставі він написав статтю й відправив її в єдиний, що існував тоді в Росії, науковий журнал. Редактор прийняв її та вирішив надрукувати в журналі. Однак сам I.I. Мечников з'ясував, що зробив помилкові висновки, прийнявши явище регенерації за розмноження. Він терміново написав до редакції, щоб зупинити друк.

Перейшовши до сьомого класу, І.І. Мечников прочитав керівництво геології харківського професора Леваковського й із юнацькою самовпевненістю написав на нею рецензію. Це була його перша друкована праця. На той час йому було шістнадцять років. Захоплений успіхами, він послав ще кілька рецензій, але вони не були надруковані.

Ілля Мечников вивчав німецьку мову, щоб в оригіналах читати класиків матеріалізму: Фіхте, Фейєрбаха, Бюхнера, Молешота. Гімназичне вчення відійшло на задній план, хоча завдяки своїм здібностям молодий учений продовжував бути гарним учнем та успішно складав іспити. Програма його майбутньої діяльності остаточно визначилася з такого приводу. У той час на книжковий ринок надходило безліч перекладів творів з природознавства. І.І. Мечников намагався прочитати їх усі. Між іншим, він прочитав у російському перекладі твір Брона «Класи й порядки тваринного світу». На доданих таблицях він уперше побачив світ мікроскопічних організмів: амеб, інфузорій. Цей світ найпростіших живих організмів настільки глибоко вразив його, що він твердо вирішив присвятити себе вивченню нижчих щаблів тваринного світу, проявам життя в її простій формі. Йому тоді було п'ятнадцять років.

I.І. Мечников мав велике бажання закінчити гімназію із золотою медаллю. Це було вагомим доказом для батьків серйозності його наукових занять з метою отримати можливість поїхати за кордон для подальшої освіти. Тому на певний час він відклав наукові дослідження й серйозно взявся за покинутий ним гімназійний курс. Остаточні іспити відбувалися навесні 1862 року. Ілля склав їх блискуче й отримав золоту медаль. Тепер усі помисли його були зосереджені на тому, щоб якомога швидше взятися за наукову роботу.

І.І. Мечников вирішує спробувати продовжити наукову діяльність за кордоном [1]. У ті часи молодь особливо приваблювали німецькі університети. У них працювала ціла плеяда знаменитих професорів і лабораторій, широко відкритих іноземцям.

Мріючи поїхати вчитися за кордон, Ілля Мечников вирішив обговорити цю ідею з матір'ю. У поїздці до Німеччини йому необхідна була їі підтримка, як моральна, так і матеріальна. Отримати її згоду було неважко, так як вона глибоко вірила в наукове майбутнє сина й від щирого серця бажала допомогти йому. Отже, незважаючи на те що потрібна була чимала сума для навчання закордоном, батьки вірили в Іллю та зібрали необхідні кошти. Майбутній науковець вирішив їхати до Вюрцбургу до відомого професора Келлікера. Ілля Ілліч обрав саме його, тому що професор читав гістологію, а І.І. Мечников хотів вивчати протоплазму. Думаючи, що в Німеччині канікули збігаються з російськими та що заняття почнуться з вересня, він поспішав потрапити туди заздалегідь. У ті часи подорож була довга, складна. Однак, незважаючи на втому, він зупинився всього на день у Берліні й поїхав купувати потрібні книги в книжковий центр Лейпциг. Після Берліну І.І. Мечников поспішив виїхати до Вюрцбургу. Виявилося, що канікули в повному розпалі. Ні Келлікера, ні інших професорів не було в місті. Заняття мали початися тільки через шість тижнів. Уперше, опинившись на самоті, серед чужих людей, Ілля Мечников зовсім розгубився.

Дізнавшись, що неподалік $€$ квартира з російськими студентами, І.І. Мечников зрадів і, повний надій, відразу вирушив до неї. На жаль, співвітчизники не були так раді бачити його, як він собі уявляв. Знайшовши собі нове житло в «сердитих людей похилого віку», I.І. Мечников не встиг розкласти одяг, як вирішив їхати на вокзал і першим потягом повернувся назад до Панасівки. Поява І.І. Мечникова вдома, звичайно, викликала загальне здивування. Проте, побачивши його хвилювання, 
батьки прийняли Іллю благодушно. У глибині душі мати була рада його поверненню, так як відпускала його зі страхом.

Так скінчилася його перша поїздка за кордон. Імовірно, всього цього б і не було, якби не такий збіг обставин і непристосованість молодого вченого до самостійності. Ці обставини змінили його плани та мрії на майбутнє.

Ілля Мечников, обговоривши з батьками перспективи навчання, вирішує вступати до Харківського університету. В І.І. Мечникова виникло бажання вступити на медичний факультет. Однак мати відмовила його, аргументуючи це тим, що в нього надто м'яке серце: «... ти не будеш в змозі постійно бачити страждання людей» [7]. І.І. Мечников вирішив дослухатися думки матері та І.П. Щелкова, який порадив вступити на природничий факультет, «більш відповідний для суто наукової діяльності».

В університеті юнак учився недовго (18621864). Це пов'язано з тим, що його не влаштовували темп навчання й той факт, що більшість викладачів використовують застарілі знання. I.I. Мечникова також засмучував формальний підхід професорів до лекцій і відсутність практичних занять. Однак Ілля Ілліч надихався знаннями хіміка О.М. Бекетова та фізіолога І.П. Щелкова. На думку І.І. Мечникова, вони давали сучасні знання.

Під час відвідування Німеччини, I.I. Мечников купив собі багато наукових творів і книжок, серед яких був переклад «Походження видів» Дарвіна. Еволюційна теорія вразила молодого вченого. Він став досліджувати нові види тварин, які до цього його не цікавили. Під керівництвом професора фізіології І.П. Щелкова Ілля написав чотири наукові роботи: дві - про скорочення стебла інфузорії, одну - про новий вид червів, одну - про паразитизм інфузорій. Так, у лабораторії, досліджуючи нові види та друкуючи свої результати, закінчив перший курс навчання в університеті. Самостійно працюючи в лабораторії І.П. Щелкова, І.І. Мечников надрукував результати роботи в 1863 році в «мюллерівському Архіві». Незабаром з'явилася стаття знаменитого фізіолога Кюне, який зухвало, різко спростовував його. Це вкрай засмутило молодого вченого. І.І. Мечников негайно повторив досліди й, отримавши колишні результати, відповів Кюне також досить різко, зачеплений тоном його статті.

Ілля Ілліч досить рано став писати наукові статті. У результаті проведених ним спостережень за інфузоріями він підготував статтю на тему «Деякі факти із життя інфузорій». I.І. Мечников відправив її в науковий журнал «Бюлетень Московського суспільства дослідників природи». Редактор прийняв статтю й вирішив надрукувати ії в журналі. Однак сам I.І. Мечников з'ясував, що зробив помилкові висновки, прийнявши явище регенерації за розмноження й написав до редакції, щоб зупинити друк.

Розуміючи, що під час навчання в університеті йому не вистачало практичних занять, I.I. Мечников вирішує пройти чотирирічну освітню програму за два роки. Отже, Ілля Ілліч за два роки засвоїв чотирирічний курс природничого відділення фізико-математичного факультету Харківського університету й успішно склав іспити. І.І. Мечников згодом писав, що в студентські роки він поспішав займатися «справжньою» наукою. Молодий учений другий рік навчання провів у підготовці до іспитів на кандидатський ступінь разом із четвертим курсом.

Отже, після старанної підготовки Іллі Мечникову вдалося скласти іспити й отримати диплом у дев'ятнадцять років. Видатний фізіолог К. Тімірязєв зазначав, що на початку 1860-х років у наукових колах Петербургу ходили чутки про вундеркінда, який з'явився в Харкові. Цей юнак мало не на гімназійній лавці навчився володіти мікроскопом і навіть друкується в іноземних журналах. Мова тоді йшла про юного 19-річного Іллю Мечникова.

Час, який Ілля Мечников провів в університеті, був досить незначним. Він не зміг побудувати товариські взаємини з одногрупниками. Усі його зусилля були спрямовані на навчання, досліди та наукову діяльність.

У 1864 році І. Мечников закінчив з відзнакою університет і відбув до Європи для подальшого навчання та практичної діяльності. Згодом працював на о. Гельголанд у Північному морі, потім у Гіссенському університеті Німеччини. Там він працював у лабораторії професора Р. Лейкарта. У цей час йому вдалося відкрити складний цикл розвитку (чергування поколінь) у паразитичних нематод [1;2].

У 1865 році І.І. Мечников переїжджає в Heaполь вивчати морських тварин. Там він працює із зоологом О.О. Ковалевським. Досліджуючи багату фауну Середземного моря, молоді науковці здобули значний матеріал для наукових спостережень. Вони вивчили велику кількість медуз, губок, голкошкірих, молюсків і зробили висновок, що ембріональний розвиток безхребетних підлягає тим самим законам, що й розвиток вищих хребетних тварин [1]. Дослідження О.О. Ковалевського та І.І. Мечникова заклали основи нової науки - еволюційної ембріології. У 1867 році вчені отримали премію К. Бера, яка присуджувалася за праці з ембріології.

Уже у віці 22 роки Ілля Ілліч захистив магістерську дисертацію на тему «Історія ембріонального розвитку Sepiola». Через рік, у 1868 році, він захистив дисертацію на тему «Історія розвитку Nebalia» на здобуття наукового ступеня доктора зоології в Петербурзькому університеті [9, с. 53-62]. 
Якщо аналізувати особистісні якості І.І. Мечникова, то можна визначити такі: сформована вольова сфера, активність, мотивованість, високий рівень інтелекту тощо. І.М. Сеченов писав про І.І. Мечникова: «З усіх молодих людей, яких я знав, більш захоплюючого, ніж молодий Ілля Ілліч, за рухливістю розуму, невичерпною дотепністю й різнобічною освітою я не зустрічав у житті. Наскільки він був серйозний і продуктивний у науці, уже тоді він зробив у зоології дуже багато й мав у ній велике ім'я, настільки ж живий, цікавий і різноманітний у дружньому товаристві» [10, с. 136].

Висновки 3 проведеного дослідження. Отже, аналізуючи біографію видатного науковця, узагальнили умови формування видатного вченого з погляду теорії розвитку творчого мислення та феномена наукового таланту І.І. Мечникова.

На нашу думку, пошук особистістю власної цілісності може бути фактором спроможності робити наукові відкриття, тому що потреба розвитку особистості може призводити до розвитку суспільства шляхом вивчення нових творів, теорій (ноосфера), винаходів. Аналіз студентських років Іллі Ілліча Мечникова характеризує особливості розвитку його наукового мислення та формування таланту. Розглянувши умови навчання в гімназії та університеті, можемо надати загальну характеристику чинників:

1. Майбутній науковець займав активну позицію в освітньому процесі, тісно взаємодіяв з учителями та професорсько-викладацьким складом, на нього впливала плеяда видатних учених того часу.

2. І.І. Мечников мав високий інтерес і мотивацію до наукової діяльності.

3. І.І. Мечников здобув вищу освіту в провідному університеті країни.

4. І.І. Мечников брав активну участь у дослідженнях університету.

Перспективою подальших досліджень може стати професійне становлення й науковий шлях I.I. Мечникова, визначення значущих періодів у житті Іллі Ілліча та наявність чіткого зв'язку між цими періодами й створеними ним науковими працями. Це в майбутньому допоможе створити модель розвитку творчих здібностей особистості, які врахують змістово-структурні елементи розвитку особистості на всіх етапах її життя.

\section{ЛІТЕРАТУРА:}

1. Галушка Р.А., Кучма И.Ю., Глазунова Л.И. И.И. Мечников - основатель современной микробиологии и иммунологии. Annals of Mechnikov Institute. 2011. № 1. C. 64-67. URL: http:// imiamn.org.ua / journal.htm.

2. Галушка Р.А., Кучма И.Ю., Глазунова Л.И. Научная деятельность И.И. Мечникова за рубежом. Annals of Mechnikov Institute. 2011. № 2. C. 65-69. URL: http://imiamn.org.ua/ journal.htm.

3. Зайцева Н.В. Педагогическая деятельность И.И. Мечникова в Новороссийском университете: своеобразие подхода к процессу обучения студентов. Образование и общество. URL: http:// jeducation.ru/6_2009/102.html.

4. Иваненко М.О., Климова Е.М., Кузьменко Е.В. И.И. Мечников. Формирование научного мировоззрения в детские и юношеские годы. Ученые записки Таврического национального университета им. В.И. Вернадского. Серия «Биология, химия». 2011. № 1. С. 40-51.

5. Мечников И.И. Письма / под редакцией А.Е. Гайсиновича, Б.В. Лёвшина. Москва : Наука, 1974. 296 C.

6. Мечникова О.Н. Жизнь Ильи Ильича Мечникова. Москва - Ленинград : Государственное изд-во, 1926. 232 c.

7. Мечникова О.Н. Музей памяти И.И. Мечников. Москва - Ленинград : Госмедиздат, 1930. 71 с.

8. Могилевский В. Жизнь Мечникова. Харьков : Харьковское областное изд-во, 1955. 296 с.

9. Петрюк П.Т., Кучма И.Ю., Резник В.И. Илья Ильич Мечников: биографические, научные и психиатрические аспекты (к 165-летию со дня рождения). Annals of Mechnikov Institute. 2010. № 2. C. 53-62.

10. Сеченов И.М. Автобиографические записки Ивана Михайловича Сеченова. Москва : Изд-во AH CCCP, 1945.

11. Чекман І.С. Україно, обітована земле мого серця! Нобелівські лауреати - вихідці з України. Вісник НАН України. 2006. № 1. С. 44-53. 